\title{
Natural Killer Cell Activity in Very Low Birth Weight Infants
}

\author{
THOMAS MCDONALD, JANE SNEED, WILLIAM R. VALENSKI, MICHAEL DOCKTER, \\ RICHARD COOKE, AND HENRY G. HERROD \\ Departments of Pediatrics, Medicine, and Microbiology-Immunology and the Molecular Resource Center, \\ University of Tennessee, Memphis, Tennessee 38163
}

\begin{abstract}
The exact role of natural killer (NK) cells in host defense is unclear, but they may be important as an early response to certain infections. We evaluated NK cell phenotype and activity in premature very low birth weight infants (VLBWI) $(n=52)$ with an average gestational age of 29.3 wk (24-35 wk) and an average birth weight of 1124 $\mathrm{g}(537-1480 \mathrm{~g})$. All patients initially were evaluated within $7 \mathrm{~d}$ of birth. Samples also were obtained at 2,4 , and 6 wk in some infants. The proportion of mononuclear cells expressing the phenotypic marker of NK cells (NKH-1; CD56) was significantly lower in VLBWI than in adults (2.5 \pm 1.4 versus, $12.5 \pm 7.8 \%, p<0.0001)$ or term infants $(2.5 \pm 1.4$ versus $9.5 \pm 7.1 \%, p<0.0001)$. VLBWI also had significantly diminished NK activity expressed as the percentage of specific lysis compared with adults $(4.7 \pm$ 4.4 versus $32.3 \pm 14.5 \%, p<0.0001)$ or term infants $(4.7$ \pm 4.4 versus $15.5 \pm 10.8 \%, p<0.0001$ ). Both the number of cells expressing the NK phenotype and the NK lytic activity in VLBWI increased in the 6 wk after birth. NK activity in VLBWI was enhanced by IL-2 and in most cases by interferon- $\gamma$. (Pediatr Res 31: 376-380, 1992)
\end{abstract}

Abbreviations

\author{
$\gamma$-IFN, $\gamma$-interferon \\ NK, natural killer \\ VLBWI, very low birth weight infant \\ $\mathrm{E} / \mathrm{T}$, effector/target
}

NK cells are capable of lysing tumor cells, virally infected cells, bacteria, and some normal cells in the absence of previous sensitization (1-6). These cells have been postulated to be important as an early defense mechanism in protecting the host against infection (7-9). If this concept is valid, then NK cells may be particularly important for protection of infants before maturation of the immune system.

Many factors adversely affect NK activity in adults, including glucocorticoids (10), prostaglandin $\mathrm{E}_{2}$ (11), iron deficiency (12), fever (13), elevated blood sugar (14), and decreased proportions of NK-associated cells (15). Previous studies have established that term infants have decreased NK activity compared with adults, yet they have similar proportions of cells expressing the NK-associated antigens NKH-1 and Leu-11a (15--22). Diminished NK activity in the full-term infant has been related to variations of the above factors together with developmentally immature NK cells (15-19). A limited number of studies involving premature infants indicate that they have less NK activity

Received September 16, 1991; accepted November 12, 1991

Reprint requests: Henry G. Herrod, M.D., Pediatric Research, University of Tennessee, Memphis, 956 Court Avenue, Rm. B310, Memphis, TN 38163. than do term infants $(23,24)$ as well as fewer cells bearing an NK phenotype (18).

Exogenous IL- 2 and $\gamma$-IFN can enhance NK activity and promote NK cell proliferation in term infants and adults (25$30)$. Decreased lymphokine production and responsiveness to lymphokines have been suggested as contributing to this reduced activity $(9,19,23-38)$. Ueno et al. (24) and Uksila et al. (25) have also demonstrated lymphokine enhancement of NK activity in premature infants. In term infants, NK activity is diminished in cord blood and for the first several days postnatally but rapidly increases, rising to almost adult levels by $1-5$ mo of age $(8,16$, 19). Studies on postnatal NK cell development in premature infants are limited.

In this study, we evaluated NK activity in premature VLBWI, in cord blood of normal term infants, and in normal adults. We also assayed for NK phenotype and ability to produce and respond to the lymphokines IL-2 and $\gamma$-IFN. Our findings indicate that NK activity in VLBWI is decreased compared with both term infants and adults. This deficiency is probably due to decreased lymphokine production (as previously described for term infants), as well as a decrease in the number of functionally mature NK cells.

\section{MATERIALS AND METHODS}

Study groups. Heparinized blood specimens from a total of 52 preterm infants (all VLBWI) with an average gestational age of $29.3 \mathrm{wk}$ (range 24-35 wk) and average birth weight of $1124 \mathrm{~g}$ (range $537-1480 \mathrm{~g}$ ) were collected within $7 \mathrm{~d}$ of birth and when possible at 1,2, 4, and $6 \mathrm{wk}$ after the initial sample. Cord blood specimens from 26 term infants with an average gestational age of 38.9 wk (range 35-41 wk) and birth weight of $3187 \mathrm{~g}$ (range $2495-3941 \mathrm{~g}$ ) were evaluated. Blood from 44 adult volunteers was also studied.

Preparation of cells. Mononuclear cells were isolated from all blood samples using a modified Ficoll-Hypaque gradient. The mononuclear fractions were then washed three times in PBS with $2 \%$ FCS. Viability was determined using trypan blue vital stain, and cells were counted and suspended in media (RPMI $1640,10 \%$ FCS, $2.5 \% N$-2-hydroxyethylpiperazine- $N^{\prime}$-2-ethane, $1 \%$ glutamine) for NK assays or PBS with $2 \%$ FCS for phenotype analysis.

Phenotype analysis. Direct conjugate fluorescein-isothiocyanate-labeled anti-Leu-11a (CD16; Becton Dickinson, Parsippany, NJ) and phycoerythrin-labeled anti-NKH-1 (CD56; Coulter Immunology, Hialeah, FL) MAb were incubated at $4^{\circ} \mathrm{C}$ for $30 \mathrm{~min}$, washed, and counted on a Coulter EPICS flow cytometer. Direct dye conjugates of matching isotype Ig were used as controls. The cell population was selected for analysis using forward angle and side light scatter bitmap gating.

Cytotoxic assay. A ${ }^{51} \mathrm{Cr}$ cytolytic assay was used to determine $\mathrm{NK}$ activity. K562 target cells were labeled with $100 \mu \mathrm{Ci}{ }^{51} \mathrm{Cr}$ sodium chromate (Amersham, Arlington Heights, IL). After 
washing, $10^{4}$ cells in $100 \mu \mathrm{L}$ of test medium (RPMI 1640, glutamine, $10 \%$ FBS, and $10 \mathrm{mM} \mathrm{N}$-2-hydroxyethylpiperazine$N^{\prime}$-2-ethanesulfonic acid) were added to each well of a U-bottomed microtiter plate. Two-fold dilutions of effector cells were then added to $100 \mu \mathrm{L}$ of test medium and incubated for $4 \mathrm{~h}$ at $37^{\circ} \mathrm{C}$. Final $\mathrm{E} / \mathrm{T}$ ratios varied from $50: 1$ to $6: 1$. The supernatants from the ${ }^{51} \mathrm{Cr}$-labeled target cells were harvested and tested for radioactivity in a gamma scintillation counter. The means from triplicate or quadruplicate tests were used to determine the percentage of specific cytotoxicity (PSC), expressed as the percentage of the total release corrected for the spontaneous release in the absence of effector cells:

$$
\text { PSC }=(\text { test } \mathrm{cpm}-\text { spon } \mathrm{cpm} \div \text { total } \mathrm{cpm}-\text { spon } \mathrm{cpm}) \times 100
$$

Spontaneous release did not exceed $10 \%$.

Anti-IL-2 receptor assay. A total of $2.5 \times 10^{5}$ cells in $200 \mu \mathrm{L}$ were preincubated for $20 \mathrm{~min}$ in media containing anti-Tac (anti-CD25; Becton Dickinson) at $37^{\circ} \mathrm{C}$. After incubation, the samples in media containing anti-CD25 were assayed for NK lytic activity both with and without the addition of IL-2.

Twenty-four $h I L-2$ transformation. VLBWI, full-term, and adult cell samples were assayed for NK phenotype and lytic ability before and after $24 \mathrm{~h}$ incubation with and without IL-2. Each initial sample was divided into three groups. The first group was immediately assayed, the second group was assayed after 24 $\mathrm{h}$ incubation in RPMI, and the third group was incubated $24 \mathrm{~h}$ in RPMI media with $200 \mu \mathrm{g} / \mathrm{mL}$ IL-2 and then assayed.

Cytokine assays. Cell samples of $1 \times 10^{6}$ cells $/ \mathrm{mL}$ were stimulated with $5 \mu \mathrm{L}$ phytohemagglutinin and $5 \mathrm{ng}$ phorbal myristate acetate in RPMI media for $24 \mathrm{~h}$ at $37^{\circ} \mathrm{C}$. Supernatant from these cultures was evaluated for the concentration of IL-2 using Intertest 2 Human Interleukin-2 ELISA test kit (Genzyme Corp. Boston, MA) and for $\gamma$-IFN using Centocor Gamma Interferon Radioimmunoassay (Centocor, Inc.). To study the effect of cytokines on NK activity, IL-2 (Cetus Corp., Emeryville, CA) or $\gamma$-IFN (Collaborative Research, Inc.) was added to cultures at the indicated concentration.

Statistical analysis. All data was log corrected before analysis. The $t$ test was adopted for the analysis of unpaired samples with $p<0.05$ considered significant.

\section{RESULTS}

NK cell phenotype. Flow cytometric analysis showed a decreased proportion of CD56 (NKH-1)-positive cell present in VLBWI (sampled within 1 wk of birth) compared with both term infants and adults (Table 1). The proportion of NKH-1 cells seen in term infant samples was not significantly different from adults. Similarly, cells expressing the CD16 (Leu-1 1a) antigen were also significantly lower in VLBWI compared with term infants or adults. There was no difference in the proportion of CD16 cells between term infants and adults.

Within the VLBWI study group, there were no differences in either CD56 or CD16 on the basis of gestational age (28-30 wk versus 31-34 wk), birth weight ( $<900 \mathrm{~g}$ versus $>900 \mathrm{~g})$, APGAR scores at $1 \mathrm{~min}$ and $5 \mathrm{~min}(0-5$ versus $6-10$ at either time point), or sex of the infant.

Table 1. Comparison of NK phenotypes and NK activity in VLBWI, full-term infants, and adults*

\begin{tabular}{lcccc}
\hline & & $\% \mathrm{CD} 56$ & $\% \mathrm{CD} 16$ & $\begin{array}{c}\% \mathrm{NK} \\
\text { target lysis } \\
\end{array}$ \\
& $n$ & $(\mathrm{NKH}-1)$ & $($ Leu-1 1a) & $(25: 1)$ \\
\hline VLBWI & 56 & $2.5 \pm 1.4 \dagger$ & $5.1 \pm 3.2 \dagger$ & $4.7 \pm 4.4 \dagger$ \\
Full-term infants & 26 & $9.5 \pm 7.1$ & $12.8 \pm 9.9$ & $15.5 \pm 10.8 \ddagger$ \\
Adults & 44 & $12.5 \pm 7.8$ & $11.2 \pm 6.1$ & $32.3 \pm 14.5$ \\
\hline
\end{tabular}

* Values represent mean $\pm 1 \mathrm{SD}$.

$\dagger p<0.0001$ relative to either term infants or adults.

$\ddagger p<0.0001$ relative to adults.
NK cell activity. NK lysis was determined for VLBWI, term infants, and adult donors using a $4-\mathrm{h}{ }^{51} \mathrm{Cr}$ release assay (Table 1). Table 1 shows the data for lysis at a $25: 1 \mathrm{E} / \mathrm{T}$ ratio, but a similar relationship among the groups existed at $\mathrm{E} / \mathrm{T}$ ratios of $50: 1$ and $12.5: 1$. NK lysis in the VLBWI group was markedly decreased compared with either term infants or adults. Activity of full-term infants was also significantly decreased when compared with adult activity. There was no difference in NK activity within the VLBWI group when grouped according to the parameters used above.

There was poor correlation between the proportion of $\mathrm{NKH}$ 1 -positive cells and NK activity in VLBWI. The correlation coefficient between the percentage of NK cells and the percentage of lysis was 0.511 , with an $R^{2}$ of 0.261 .

NK cell number and activity after birth. Our study of samples from the VLBWI obtained over a period of $6 \mathrm{wk}$ demonstrated an increase in both the proportion of NK cells and lytic activity (Fig. 1). Samples obtained 6 wk after entry into the study had a higher proportion of CD56 cells $(p=0.0149)$ and a higher percentage of lysis $(p=0.0015)$ than were found in the studies done during the 1 st wk of life.

Effect of IL-2 and $\gamma-I F N$ on NK activity. Exogenous IL-2 or $\gamma$-IFN added to the media in the ${ }^{51} \mathrm{Cr}$ release assay increased NK cytolytic activity in VLBWI $(n=43)$, term infants $(n=6)$, and adults $(n=21)$. IL-2 always increased NK lytic activity, whereas $\gamma$-IFN was inconsistent, with several of the VLBWI having no response to $\gamma$-IFN. Although IL-2 enhanced NK activity in each study group, the VLBWI demonstrated a significantly greater relative response than adults based on the overall percentage of increase in activity (VLBWI $153 \%$ versus adults $70 \%, p=$ 0.0279 ). Term infants also showed more enhancement with IL2 than did adults (term infants $106 \%$ versus adults $70 \%, p=$ 0.179 ). Within the VLBWI population, there was no difference in the degree of IL-2 enhancement when infants were grouped by weight, gestational age, or sex.

Cell samples were also cultured with and without IL-2 for 24 $h$ to determine the effect on NK phenotype expression and activity compared with preculture levels. Samples assayed after $24 \mathrm{~h}$ in IL-2-supplemented media had no significant increase in NK phenotype when compared with the d-l samples or the $24-$ $\mathrm{h}$ controls (Table 2). This was true for all three groups. Incubation in IL-2 consistently increased NK lytic activity in all groups tested. There also was a small increase in NK activity seen in the control cultures incubated in unsupplemented media for $24 \mathrm{~h}$.

Preliminary studies of VLBWI $(n=2)$ and adults $(n=2)$ indicate that preincubation with anti-CD25 decreases natural killing capacity in both groups (Table 3). Anti-CD25 inhibition could be partially reversed in all groups by the addition of IL-2 to the preincubated cells at the time of the assay.

$I L-2$ and $\gamma-I F N$ production. Lymphokine production was determined by quantitating IL-2 and $\gamma$-IFN concentrations in the

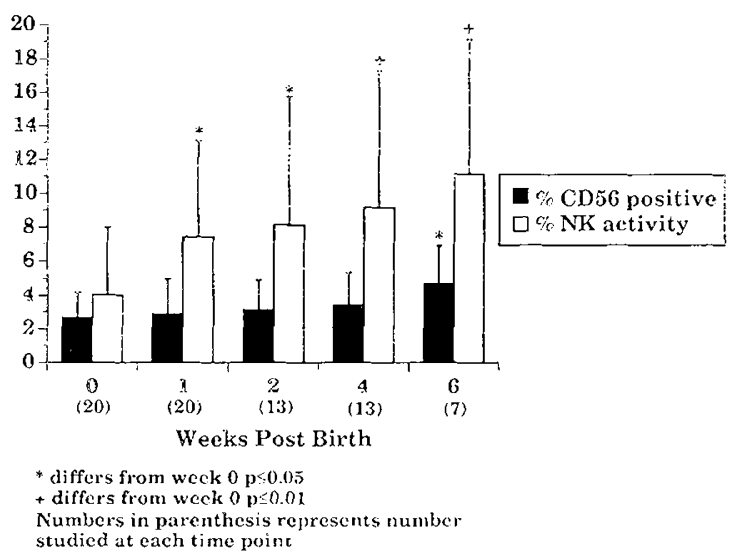

Fig. 1. Changes in the proportion of CD56-positive cells and NK activity occurring over a 6 -wk interval in VLBWI. 
Table 2. Comparison of $N K$ cell phenotype and activity level after 24 h incubation with $I L-2$ in VLBWI, full-term infants, and adults*

\begin{tabular}{cccccc}
\hline & \multicolumn{2}{c}{ Day 0 (\% lysis) } & & \multicolumn{2}{c}{ Day 1 (\% lysis) } \\
\cline { 5 - 6 } & $\begin{array}{c}\text { Media } \\
\text { alone }\end{array}$ & $\begin{array}{c}\text { Media } \\
+ \text { IL-2 }\end{array}$ & & $\begin{array}{l}\text { Media } \\
\text { alone }\end{array}$ & $\begin{array}{r}\text { Media } \\
\text { + IL-2 }\end{array}$ \\
\hline VLBWI & & & & & \\
NKH-1 & 3.7 & ND & & 4.8 & 4.3 \\
NK lysis & 2.8 & 12.8 & & 12.2 & 62.1 \\
Term & & & & \\
NKH-1 & 3.9 & ND & & 5.1 & 4.9 \\
NK lysis & 9.1 & 17.5 & & 20.2 & 80.0 \\
Adults & & & & \\
NKH-1 & 13.2 & ND & & 10.7 & 10.7 \\
NK lysis & 38.1 & 51.5 & & 44.9 & 80.9 \\
\hline
\end{tabular}

* Studies represent mean from five subjects in each group. ND, not determined.

Table 3. NK activity in VLBWI and adults after preincubation with anti-Tac antibody

\begin{tabular}{|c|c|c|c|c|c|}
\hline & \multirow[b]{2}{*}{ Experiment } & \multicolumn{4}{|c|}{ \% Lysis $25: 1$ ratio } \\
\hline & & Media & Anti-Tac* & $\begin{array}{c}\text { Anti-Tac } \\
+ \text { IL-2 } †\end{array}$ & $\begin{array}{l}\text { IL-2 } \\
\text { alone }\end{array}$ \\
\hline \multirow{2}{*}{ VLBWI } & A & 16.1 & 3.4 & 14.7 & 34.7 \\
\hline & B & 10.1 & 3.4 & 6.9 & 18.3 \\
\hline \multirow[t]{2}{*}{ Adults } & $\mathrm{A}$ & 25.3 & 17.3 & 23.6 & ND \\
\hline & B & 45.1 & 14.4 & 20.8 & 55.4 \\
\hline
\end{tabular}

* Samples were preincubated $20 \mathrm{~min}$ with $20 \mu \mathrm{L}$ anti-Tac before the chromium release assay.

† IL-2 was added to each well $(200 \mu \mathrm{g} / \mathrm{mL})$ at the beginning of the assay.

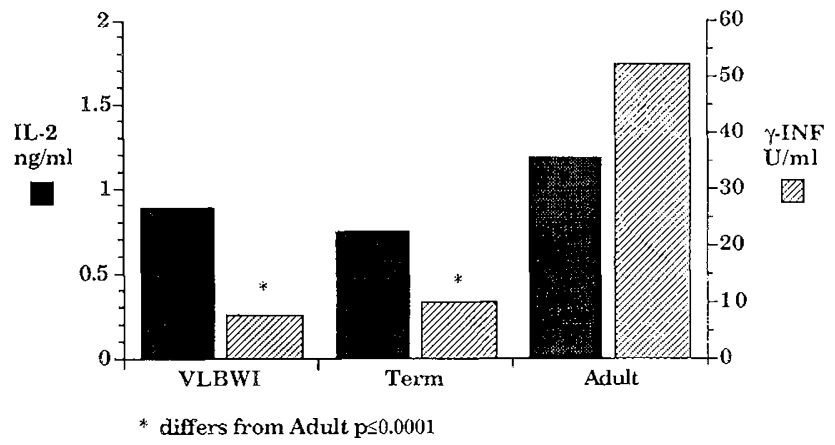

Fig. 2. In vitro production of IL-2 and $\gamma$-IFN by cells from patients in each study group.

culture supernatant after stimulation with phorbol myristate acetate and phytohemagglutinin. Although there was wide variation in cytokine production within each group, when compared with adult samples, both VLBWI and term infants produced significantly less $\gamma$-IFN (Fig. 2). IL-2 production was similar in all groups.

\section{DISCUSSION}

The role of NK cells in protecting the neonate from infectious agents in the environment is poorly understood (1-5). Previous studies have shown that cord blood from term infants has decreased NK activity compared with adult blood $(8,9,15-18,23$, 28 ), but the actual basis for this has not been determined. Limited studies have been designed to evaluate NK function in the VLBWI either near birth or postnatally. In addition, few studies have examined the basis for the decreased NK activity in the VLBWI.

In this study, we compared NK cell function in VLBWI, normal term infants, and adults. We examined the postnatal development of NK cell activity in the VLBWI and looked at potential mechanisms for explaining the decreased NK cell function seen in VLBWI and cord blood of term infants. Our study confirmed previous works that describe term infants as having similar numbers of cells bearing markers of the NK phenotype as adults $(19-24,29,31,33)$. We also demonstrated that, despite approximately equal proportions of NK cells, the overall cytotoxic function is decreased in term infants. The VLBWI that we studied had a lower proportion of NK cells and less lytic ability than did the term infants.

Ligthart et al. (39) have reported in aged populations that the proportion of NK cells correlates well with the level of NK activity. In infants this does not appear to be the case, but the actual mechanism for the decreased lysis seen in both the term and the premature infants is not known. Previous studies have suggested that this may be related to a defect in the recycling process of the NK cell $(19,34)$, decreased target binding $(8,9$, $31)$, immature NK cells $(8,15,19,23)$, and, in the case of premature infants, a decrease in the proportion of NK cells (as demonstrated in this study). Yabuhara et al. (19) and Sancho et al. (23) both reported that the proportion of term infant NK cells correlated poorly with NK activity. We noted that this was also true for VLBWI. This lack of correlation is consistent with mixed functional capabilities within the NK cell population. Without studying individual cellular killing capacities by using single cell assays (24), we were unable to determine the nature of this defect. It is of interest that Sancho et al. (23) identified "mature" and "immature" NK cells in infants that expressed varied NK activity.

Our studies in VLBWI demonstrate an increase in both the proportion of NK cells and lytic ability postnatally. This is a relatively rapid process, inasmuch as by $6 \mathrm{wk}$ of age there were statistically significant increases in both categories. A rapid increase in NK cell lysis has been demonstrated after birth in term infants $(8,16)$, with near-adult levels reached at $1-5$ mo (19). The reason for these increases is not known, but they may be related to the recruitment of pre-NK cells, the maturation of functionally immature NK cells, or proliferation of existing NK cells.

NK activity is enhanced by various lymphokines, including IL-2 and $\gamma$-IFN $(9,23,24,26-28,30,40,41)$. We examined the response to both IL-2 and $\gamma$-IFN on the assumption that NK activity in the VLBWI might be diminished because of poor responsiveness to lymphokines. Our results demonstrate that VLBWI seem to respond to exogenous IL-2 or $\gamma$-IFN stimulation with a greater relative increase in activity than do adult cells. This is due in part to the fact that adult NK activity is already so high that it is unlikely to have the proportional enhancement seen in populations such as VLBWI starting at a lower baseline. Others $(9,17,19,29)$ have reported that term infants respond to IL-2 to a greater degree than do adults, although in our study there was no significant difference seen in the percentage of increase in lysis between these groups. As others have previously demonstrated $(23-25,32,40)$, we found that $\gamma$-IFN enhancement of NK activity was inconsistent. This variable response in VLBWI to $\gamma$-IFN may be secondary to the ability of $\gamma$-IFN to influence only those cells bearing a more mature NK phenotype.

It has been hypothesized that one way that IL- 2 enhances NK activity is by the recruitment of pre-NK cells $(26,28)$. Others have found that an 18-h incubation with IL-2 produced a large increase in NK activity, but no increase in cells expressing Leu11a. Our study showed a similar increase in NK activity when cells were incubated with IL-2 without an increase in the number of cells expressing CD56. This observation was true for all three study groups. The failure to induce additional cells to express $\mathrm{NKH}-1$ indicates that the IL-2-mediated increase in NK activity is probably not the result of rapid differentiation of pre-NK cells into more phenotypically mature appearing NK cells. Of interest is the fact that there is an increase in NK activity in cells 
incubated from 18 to $24 \mathrm{~h}$ in media alone. The mechanism for this is unknown (23).

Several studies have shown that IL-2-induced $\gamma$-IFN can be inhibited by the anti-IL-2 receptor antibody anti-Tac (antiCD25), yet anti-Tac does not seem to affect cytotoxicity $(26,35-$ 37). By contrast, van de Griend et al. (38) found that IL-2 enhancement was reduced by the addition of anti-Tac. Consistent with van de Griend's findings, our initial experiments indicate that preincubation with anti-CD25 decreases NK activity not only in adults but also in VLBWI. Our preliminary work used few subjects, but each showed a marked decrease in activity when their cells were preincubated with anti-CD25. This inhibition could be partially reversed if exogenous IL- 2 was added to the media at the time of assay. Although the actual mechanism of inhibition is not known, the reversal may be due to the IL-2 molecule having a greater affinity for the receptor than antiCD25 (26) or the presence of two different receptors $(26,34-37)$. Our findings that preincubation of NK cells with anti-CD25 inhibits spontaneous NK activity of adult and VLBWI and that this inhibition can partially be reversed by adding IL-2 suggest that IL-2 is an important component of the spontaneous NK cytolytic process.

Another possible basis for reduced NK activity in VLBWI is diminished cytokine production. Like others, we found that term infants $(9,26-31)$ and VLBWI (24) produced significantly lower levels of $\gamma$-IFN than did adults under similar conditions. Although there has been conflicting data on IL-2 production by neonates (41), we found similar IL-2 production by each of the three study groups as previously noted by others $(31,42-44)$.

Based on our study, as well as others, it appears the decreased NK cell function in VLBWI is secondary to a reduced proportion of relatively mature NK cells. Decreased production of factors such as $\gamma$-IFN may also contribute. An improved understanding of the role of $\mathrm{NK}$ activity in neonates could lead to therapeutic interventions designed to enhance this form of host protection.

\section{REFERENCES}

1. Herberman RB 1986 Natural killer cells. Annu Rev Med 37:347-352

2. Beverley P 1981 Understanding natural killer cells. Nature 291:288

3. Herberman RB, Ortaldo JR 1981 Natural killer cells: their role in defense against disease. Science 214:24-30

4. Trinchieri G 1989 Biology of natural killer cells. Adv Immunol 47:187-376

5. Jondal M 1987 The human NK cell: a short over-view and an hypothesis on NK recognition. Clin Exp Immunol 70:255-262

6. Gracia-Penarrubia P, Bankhurst AD, Foster FT 1989 Experimental and theoretical kinetics study of antibacterial killing mediated by human natural killer cells. J Immunol 142:1310-1317

7. Read SE, Williams BR 1984 The host defense system in the human newborn: the role of interferon and the natural killer cells. Clin Invest Med 7: 259-262

8. Baley JE, Schacter BZ 1985 Mechanism of diminished natural killer activity in pregnant women and neonates. J Immunol 134:3042-3048

9. Nair MP, Menon M, 1985 Association of decreased natural antibody-dependent cellular cytotoxicity and production of natural killer cytotoxic factor and interferon in neonates. Cell Immunol 94:159-171

10. Cavallo R, Sartori ML, Gatti G, Angeli A 1986 Cortisol and immune interferon can interact in the modulation of human natural killer cell activity. Experientia 42:177-179

11. Gatti G, Cavallo R, Sartori ML, Marinone C, Angeli A 1986 Cortisol at physiological concentrations and prostaglandin $\mathrm{E} 2$ are additive inhibitors of human natural killer cell activity. Immunopharmacology 11:119-128

12. Lockwood JF, Sherman AR 1988 Spleen natural killer cells from iron-deficient rat pups manifest an altered ability to be stimulated by interferon. $J$ Nutr 118:1558-1563

13. Dinarello CA, Dempsey RA, Allegretta M, LoPreste G, Dainiak N, Parkinson DR, Mier JW 1986 Inhibitory effects of increased temperature on human cytokine production and natural killer activity. Cancer Res 46:6236 -6241

14. Engelhard D, Warner JL, Kapoor N, Good RA 1986 Effect of intravenous immune globulin on natural killer cell activity: possible association with autoimmune neutropenia and idiopathic thrombocytopenia. $\mathrm{J}$ Pediatr 108 : $77-81$

15. Toder V, Durdana A. Elrad H, Gleicher N 1985 Natural killing (NK) potential of cord blood lymphocytes. J Clin Immunol 17:29-32

16. Kuo YC, Lin CV, Cheng SF, Lin CC, Liu WT 1986 Studies of a natural killer cell activity in the healthy Chinese. Chung Hua Min Kuo Wei Sheng Wu Chi Mien I Hsueh Tsa Chih 19:112-117

17. Montagna D, Maccario R, Ugazio AG, Mingrat G, Burgio GR 1988 Natural cytotoxicity in the neonate: high levels of lymphokine activated killer (LAK) activity. Clin Exp Immunol 71:177-181

18. Abo T, Cooper MD, Balch CM 1983 Differentiation stages of human natural killer cells in lymphoid tissue from fetal to adult life. J Exp Med 157: 273-284

19. Yabuhara A, Kawai $H$, Komiyama A 1990 Development of natural killer cytotoxicity during childhood: marker increases in number of natural killer cells with adequate cytotoxic abilities during infancy to early childhood. Pediatr Res 28:316-322

20. Hercend T, Griffin JD, Bensussan A, Schmidt RE, Edson MA, Brennam A, Murry C, Schlossman SF, Ritz J 1985 Generation of monoclonal antibodies to a human natural killer clone. J Clin Invest 75:932-943

21. Lanier LL, Le AM, Civin CI, Loken MR, Phillips JH 1986 The relationship of CD16 (Leu-11) and Leu-19 (NKH-1) antigen expression on human peripheral blood NK cells and cytotoxic T lymphocytes. J Immunol 136: $4480-4486$

22. Ritz J, Schmidt RE, Michon J, Hercend T, Schlossman SF 1988 Characterization of functional surface structures on human natural killer cells. Adv Immunol 42:181-211

23. Sancho L, de la Hera A, Casas J, Vaquer S, Martinez A, Alvarez-Mon M 1991 Two different maturational stages of natural killer lymphocytes in human newborn infants. J Pediatr 119:446-454

24. Ueno Y, Miyawaki T, Seki H, Matsuda A, Taga K, Sako H, Taniguchi N 1985 Differential aspects of recombinant human interferon-gamma and interleukin 2 on natural killer cell activity of peripheral blood in early human development. J Immunol 135:180-184

25. Uksila J, Lassila O, Hirvonen T, Toivanen P 1983 Development of natural killer cell function in the fetus. J Immunol 130:153-156

26. London L, Perussia B, Trinchieri G 1986 Induction of proliferation in vitro of resting human natural killer cells: IL-2 induces into cell cycle most peripheral blood NK cells, but only a minor subset of low density T cells. J Immunol 137:3845-3854

27. Braakman E, van Tunen A, Meager A, Lucas CJ 1986 IL-2 and IFN gammaenhanced natural cytotoxic activity: analysis of the role of different lymphoid subsets and implications for activation routes. Cell Immunol 99:476-488

28. Lange A, Flad HD, Ernst M, Jacak A, Ulmer AJ 1986 Effect of human recombinant IL- 2 on natural killing of low density Percoll fraction cells. Immunol Lett 12:243-250

29. Baker DA, Milch PO, Salvatore W, Luft B 1987 Enhancement of maternal and neonatal natural killer cell activity with interleukin-2. Am J Obstet 157: $780-781$

30. Seki H, Ueno Y, Taga H, Matsuda A, Miyawaki T. Taniguchi N 1985 Mode of in vitro augmentation of natural killer cell activity by recombinant human interleukin 2: a comparative study of leu-11+ and leu-11+ cell populations in cord blood and adult peripheral blood. J Immunol 135:2351-2356

31. Chin TW, Ank BJ, Murakami D, Gill M. Spina C. Strom S, Stiehm ER 1986 Cytotoxic studies in human newborns: lessened allogeneic cell-induced (augmented) cytotoxicity but strong lymphokine-activated cytotoxicity of cord blood mononuclear cells. Cell Immunol 103:241-251

32. Hee SO, Gonik B, Greenburg SB, Kohl S 1986 Enhancement of human neonatal natural killer cytotoxicity to herpes simplex virus with use of recombinant human interferons: lack of neonatal response to $\gamma$-interferon. J Infect Dis 153:791-793

33. Uksila J, Lassila O, Hirvonen T 1982 Natural killer cell function of human neonatal lymphocytes. Clin Exp Immunol 48:649-654

34. Kohl S, West MS, Loo LS 1988 Defects in interleukin-2 stimulation of neonatal killer cytotoxicity to herpes simplex virus-infected cells. J Pediatr 112: 976-981

35. Hellstrand K, Hermodosson S 1989 Interleukin-2 can induce suppression of human natural killer cell cytotoxicity. Clin Exp Immunol 77:410-416

36. Kerhi JH, Dukovich M. Whalen G, Katz P. Fauci AS, Greene WC 1988 Novel Interleukin 2 (IL-2) receptor appears to mediate IL-2-induced activation of natural killer cells. J Clin Invest 81:200-205

37. Iseki R, Koide Y, Ueda R, Kondo H, Hamuro J, Yoshida TO 1987 The interaction of recombinant IL-2 with human resting lymphocytes: blocking effects of monocional antibodies to IL-2 receptors. Microbiol Immunol 31 : 59-74

38. van de Griend RJ, Ronteltap CP, Grave Kamp C, Monnikendam D, Balhuis RL 1986 Interferon beta and recombinant IL-2 can both enhance, but by different pathways, the cytolytic potential of T3-natural killer cell clones rather than that of T3+ clones. J Immunol 136:1700-1707

39. Ligthart GJ, Schuit HR. Hijmans W 1989 Natural killer cell function is not 
diminished in the healthy aged and is proportional to the number of NK cells in the peripheral blood. Immunology 68:396-402

40. Henney CS, Kuribayaski K, Kern DE 1981 Interleukin-2 augments natural killer cell activity. Nature 291:335-338

41. Watson W, Oen K, Ramdahin R, Harman C 1991 Immunoglobulin and cytokine production by neonatal lymphocytes. Clin Exp Immunol 83: 169-174

42. Lewis LB, Yu CC, Meyer J, English BK, Kahn SJ, Wilson CB 1991 Cellular and molecular mechanisms for reduced interieukin 4 and interferon- $\gamma$ production by neonatal T cells. J Clin Invest $87: 194-202$

43. Dudley DJ, Mitchell MD, Creighton K, Branch DW 1990 Lymphokine production during term pregnancy: differences between peripheral leukocytes and decidual cells. Am J Obstet Gynecol 163:1890-1893

44. Pastorelli G, Rousset F, Pene J, Peronne C, Roncarolo MG, Tovo PA, de Vries JE 1990 Cord blood B cells are mature in their capacity to switch to IgEproducing cells in response to interleukin-4 in vitro. Clin Exp Immunol 82: $114-119$

\section{Announcement}

The Carnegie Foundation's most recent report, Ready to Learn: A Mandate for the Nation, proposes a national commitment to assure that by the year 2000 all children will be well prepared for school, which the President and Governors have defined as the nation's first education goal. For more information, contact: Robert Hochstein at (202) 387-7200 or Jeanine Natriello at (609) 452-1780. Copies of Ready to Learn are available for $\$ 8.00$ plus postage (bulk discounts 10-30\%) from: Princeton University Press, 3175 Princeton Pike, Lawrenceville, NJ 08648, (609) 896-1344. 